\title{
Non-immune Prophylaxis Against COVID-19 by Targeting Tolerance for Angiotensin II-Triggered SARS-CoV-2 Pathogenesis
}

\author{
Michael V. Dubina ${ }^{1,2 *}$ \\ ${ }^{1}$ State Research Institute of Highly Pure Biopreparations, St. Petersburg, Russia, ${ }^{2}$ Russian Academy of Sciences, Moscow, \\ Russia
}

Keywords: COVID-19, SARS-CoV-2, angiotensin II, pathophysiology, prophylaxis, tolerance of infection

It is a joke in Britain to say that the War Office is always preparing for the last war. But this is probably true of other departments and of other countries...

Winston S. Churchill (1)

\section{INTRODUCTION}

OPEN ACCESS

Edited by:

Marc Jean Struelens,

Université Libre de Bruxelles, Belgium

Reviewed by:

Xiaojiong Jia,

Harvard Medical School,

United States

Sergey Dikalov,

Vanderbilt University, United States

*Correspondence:

Michael V. Dubina

michael.dubina@gmail.com

Specialty section:

This article was submitted to Infectious Diseases - Surveillance,

Prevention and Treatment, a section of the journal

Frontiers in Medicine

Received: 14 September 2021 Accepted: 20 December 2021

Published: 12 January 2022

Citation:

Dubina MV (2022) Non-immune Prophylaxis Against COVID-19 by Targeting Tolerance for Angiotensin

II-Triggered SARS-CoV-2

Pathogenesis. Front. Med. 8:776903.

doi: 10.3389/fmed.2021.776903
As of December 12, 2021, 5.3 million deaths had been reported worldwide due to the coronavirus disease COVID-19, which is caused by severe acute respiratory syndrome coronavirus (SARS$\mathrm{CoV})-2$ (2). The effects of infection with this virus range from asymptomatic infection to "groundglass" pneumonia with lower airway collapse, which can result in life-threatening complications (3). Previous studies of SARS-CoV infections have shaped current medical opinion on the important features of COVID-19 pathogenesis, including viral entry, replication, and migration down the respiratory tract, resulting in airway epithelium damage, diverse immune responses, inflammation, hypoxia, and acute respiratory distress syndrome (4).

For other SARS-CoVs, the receptor for SARS-CoV-2 on the host cell surface is angiotensinconverting enzyme 2 (ACE2) (5); this enzyme reduces the local and circulating levels of angiotensin II (Ang II), which is produced by angiotensin-converting enzyme (ACE) and is a major part of the renin-angiotensin-aldosterone system and is involved in blood pressure regulation (6).

This article discusses the involvement of ACE2, Ang II, and SARS-CoV-2 in the pathogenesis of lung damage in COVID-19. Based on these considerations, it proposes prophylactic measures that could maintain the lungs' capacity for dilation, redox, and metabolic functions to protect against high-risk SARS-CoV-2 infection.

\section{SARS-COV-2 PATHOPHYSIOLOGY AND ANG II}

Early studies of SARS-CoV found that its receptor, ACE2, has a protective role in acute lung failure in vivo, as opposed to ACE (7). Moreover, experimental SARS-CoV infections of wild-type mice resulted in reduced ACE2 protein expression in the lungs, and the decreased Ace2 gene expression in knockout mice resulted in low infectivity of SARS-CoV (8). Similar to other virus-receptor interactions, when SARS-CoVs interact with ACE2 to gain entry into cells, they are endocytosed with the virus, and this loss of ACE2 from the cell surface results in increased levels of local and circulating Ang II (9). Since ACE2 is found not only in nasal and alveolar epithelial cells but also in the smooth muscle and endothelial cells of the airways $(10,11)$, the increased local production of Ang II may have a profound constrictive effect on the microvasculature and distant bronchioles. In particular, Ang II targets smooth muscle cells in the vascular wall, causing internalization and 
degradation of membrane potassium channels (12) and inducing vasoconstriction by activating angiotensin II receptor type 1 (13).

SARS-CoV-2 has a greater binding affinity for ACE2 than other SARS-CoVs $(14,15)$. Indeed, SARS-CoV-2 can severely inhibit ACE2 activity and reduce Ang II consumption, resulting in abnormally high levels of Ang II in the airways (16-18), impairing metabolic homeostasis in smooth muscle cells (19), and inducing pulmonary vasoconstriction (20). Such Ang IIinduced pulmonary vasoconstriction also occurs in hypoxia and can be restored by concomitant upregulation of ACE2 (21). Transcriptome analyses after Ang II infusion in vivo have revealed upregulation of genes involved in metabolism, whereas genes that are protective against oxidative stress were downregulated (22). Thus, vaso- and bronchoconstriction resulting from transient virus-induced Ang II elevation in distal airways might precede epithelial damage and immune responses in the initial phase of the infection. The virus-induced increase in Ang II in infected lungs is probably a key local event that promotes the contraction of arterioles and cartilagefree terminal bronchioles, resulting in lower airway collapse, pulmonary hypoxia, microcirculation reduction, impaired airway cell metabolism, and diffuse alveolar damage.

Ang II triggers a vicious cycle of pathogenesis in the lungs, as vasoconstriction decreases its subsequent elimination. In particular, SARS-CoV-2-induced downregulation of ACE2 impairs Ang II clearance and may aggravate lung damage (23). Of note, plasma levels of ACE2 and Ang II do not correlate with the clinical outcomes in patients with COVID-19 (24); thus, the concentration of Ang II in the circulation is not a reliable indicator of its local concentration in the lower airways where Ang II-induced vasoconstriction may reduce the pulmonary microcirculation.

Distinctive from immunological resistance to infection, another component of the host defense response against pathogens is tolerance, which depends on the ability of the body to regulate the production, repair and avoidance of the damage accumulated during an infection (25). In line with this concept, the initiation and severity of lung pathology due to a rapid virus-mediated increase in local Ang II levels may depend on the innate capacity of the lungs to mitigate vasoconstriction by increasing dilation as well as increasing redox and metabolic functions. Infected individuals with poor pulmonary, cardiovascular, and metabolic conditions may thus suffer from greater vascular resistance in the airway periphery, thereby reducing the ventilation-perfusion properties of the lungs and causing severe COVID-19 complications. This might explain the lower tolerance with the greater severity and mortality observed in COVID-19 patients with comorbidities (26).

\section{UNCERTAIN EFFICACY OF CURRENT COVID-19 THERAPEUTICS AND PREVENTION}

The first strategies developed by the World Health Organization and national health care authorities included oxygen support and antibiotic treatments for patients and public health measures to reduce community transmission (27). The numerous treatments being studied include off-label antiviral drugs and drugs that combat hypoxemia and coagulation disorders, in addition to immunomodulatory and anti-inflammatory therapies using convalescent plasma, glucocorticoids, and anticytokines $(28,29)$. Studies using ACE inhibitors or Ang II type 1 receptor blockers and/or delivering recombinant ACE2 to the lungs have been initiated in hospitalized patients with COVID-19 (30). Moreover, there has been an unprecedented international effort by private and public institutions to develop vaccines against SARS-CoV2 (31). Recent systemic reviews have reported that adenovirus vectors and mRNA vaccines are 65-95\% effective at preventing SARS-CoV-2 infection after full vaccination $(32,33)$.

On October 15, 2020, the world's largest randomized controlled trial on COVID-19 therapeutics found that the previously recommended remdesivir, hydroxychloroquine, lopinavir/ritonavir, and interferon regimens had little or no effect on overall mortality, initiation of ventilation, or improved prognosis of COVID-19 among hospitalized patients (34). The effects of convalescent plasma, glucocorticoids, antibiotics, anticoagulants, and other previously repurposed drugs were also insignificant $(35,36)$. The use of ACE inhibitors or Ang II type 1 receptor blockers had no clear association with COVID-19 incidence and all-cause mortality; they may be protective for patients with hypertension $(37,38)$. Social distancing and seasonality still have a greater influence on infection rates than vaccination, and new virus variants threaten renewed outbreaks. The UK, Germany, and Canada, for example, are facing a new wave of SARS-CoV-2 infection despite having some of the highest vaccination rates and strict ongoing lockdown restrictions (39). To date, no agents have proven effective at preventing SARS-CoV-2 infection $(40,41)$.

\section{A NOVEL STRATEGY FOR COVID-19 MANAGEMENT}

In a pilot study, 99 health care workers at a COVID-19 hospital were treated prophylactically with an aerosol containing glutathione, potassium, and inosine at low doses for 14 days to promote lung function (42). The rationale for this combination of drugs was that glutathione decreases smooth muscle contraction (43) and induces bronchodilation by increasing membrane hyperpolarization via potassium channels (44); extracellular potassium increases blood flow in the lungs, thus improving vasodilation (45); and inosine boosts adenosine triphosphate generation, thus protecting cells from hypoxia (46). The study found $78 \%$ efficacy (i.e., relative risk reduction in the test group compared to a control group) of this pathogenesis-based prophylaxis against SARS-CoV-2 infection. Only five participants reported mild and transient adverse effects.

The efficacy and safety of these low-dose compounds when delivered to the lung as an aerosol $(47,48)$ suggests the potential of this prophylactic strategy to prevent SARS-CoV-2 infection and to fight against COVID-19 by directly promoting lung capacity for dilation, as well as redox and metabolic 
functions. Amelioration of the initial virus-induced, Ang IItriggered pathology in the small airways by this or similar inhaled dilatation and antihypoxic therapies might appreciably prevent the occurrence and/or severity of the disease.

Furthermore, numerous available well-tolerated medications, such as $\beta 2$-adrenergic agonists, phosphodiesterase III inhibitors, and superoxide dismutase, might be repurposed to better manage the disease. The potential of this tolerance-targeted prophylaxis to defend against the disease and to improve treatment would be

\section{REFERENCES}

1. Churchill WS. The Gathering Storm. Boston, MA: Houghton Mifflin. (1948).

2. World Health Organization. Coronavirus Disease (COVID-19) Situation Reports. (2021). Available online at: https:/www.who.int/emergencies/ diseases/novel-coronavirus-2019/situation-reports (accessed December 20, 2021).

3. Guan WJ, Ni ZY, Hu Y, Liang WH, Ou CQ, He JX, et al. Clinical characteristics of coronavirus disease 2019 in China. $N$ Engl J Med. (2020) 382:1708-20. doi: 10.1056/NEJMoa200 2032

4. Cao W, Li T. COVID-19: towards understanding of pathogenesis. Cell Res. (2020) 30:367-9. doi: 10.1038/s41422-020-0 327-4

5. Hoffmann M, Kleine-Weber H, Schroeder S, Krüger N, Herrler T, Erichsen S, et al. SARS-CoV-2 cell entry depends on ACE2 and TMPRSS2 and is blocked by a clinically proven protease inhibitor. Cell. (2020) 181:27180. doi: 10.1016/j.cell.2020.02.052

6. Donoghue M, Hsieh F, Baronas E, Godbout K, Gosselin M, Stagliano $\mathrm{N}$, et al. A novel angiotensin-converting enzyme-related carboxypeptidase (ACE2) converts angiotensin I to angiotensin 1-9. Circ Res. (2000) 87:E19. doi: 10.1161/01.RES.87.5.e1

7. Imai Y, Kuba K, Rao S, Gao H, Guo F, Guan B, et al. Angiotensin-converting enzyme 2 protects from severe acute lung failure. Nature. (2005) 436:1126. doi: $10.1038 /$ nature 03712

8. Kuba K, Imai Y, Rao S, Gao H, Guo F, Guan B, et al. A crucial role of angiotensin converting enzyme 2 (ACE2) in SARS coronavirus-induced lung injury. Nat Med. (2005) 11:875-9. doi: 10.1038/nm1267

9. Rivellese F, Prediletto E. ACE2 at the centre of COVID-19 from paucisymptomatic infections to severe pneumonia. Autoimmun Rev. (2020) 19:102536. doi: 10.1016/j.autrev.2020.102536

10. Hamming I, Timens W, Bulthuis ML, Lely AT, Navis G, van Goor H. Tissue distribution of ACE2 protein, the functional receptor for SARS coronavirus. A first step in understanding SARS pathogenesis. J Pathol. (2004) 203:6317. doi: 10.1002/path.1570

11. Hou YJ, Okuda K, Edwards CE, Martinez DR, Asakura T, Dinnon KH, et al. SARS-CoV-2 reverse genetics reveals a variable infection gradient in the respiratory tract. Cell. (2020) 182:429-46.e14. doi: 10.1016/j.cell.2020.05.042

12. Leo MD, Bulley S, Bannister JP, Kuruvilla KP, Narayanan D, Jaggar JH. Angiotensin II stimulates internalization and degradation of arterial myocyte plasma membrane BK channels to induce vasoconstriction. Am J Physiol Cell Physiol. (2015) 309:C392-402. doi: 10.1152/ajpcell.00127.2015

13. Forrester SJ, Booz GW, Sigmund CD, Coffman TM, Kawai T, Rizzo V, et al. Angiotensin II signal transduction: an update on mechanisms of physiology and pathophysiology. Physiol Rev. (2018) 98:1627-738. doi: 10.1152/physrev.00038.2017

14. Shang J, Ye G, Shi K, Wan Y, Luo C, Aihara H, et al. Structural basis of receptor recognition by SARS-CoV-2. Nature. (2020) 581:2214. doi: 10.1038/s41586-020-2179-y

15. Wrapp D, Wang N, Corbett KS, Goldsmith JA, Hsieh CL, Abiona O, et al. Cryo-EM structure of the 2019-nCoV spike in the prefusion conformation. Science. (2020) 367:1260-3. doi: 10.1126/science.abb2507

16. Lundström A, Sandén P. [ACE2 and coronavirus - a question of balance and dynamics?] Lakartidningen. (2020) 117:F3S3. unaffected by mutations in the virus, as the proposed agents are not antiviral per se but are intended to break the initial vicious cycle of COVID-19 pathogenesis triggered by SARS-CoV-2 entry and replication.

\section{AUTHOR CONTRIBUTIONS}

The author confirms being the sole contributor of this work and has approved it for publication.

17. Cheng H, Wang Y, Wang G-Q. Organ-protective effect of angiotensinconverting enzyme 2 and its effect on the prognosis of COVID-19. J Med Virol. (2020) 92:726-30. doi: 10.1002/jmv.25785

18. Verdecchia P, Cavallini C, Spanevello A, Angeli F. The pivotal link between ACE2 deficiency and SARS-CoV-2 infection. Eur J Intern Med. (2020) 76:1420. doi: 10.1016/j.ejim.2020.04.037

19. Hitomi H, Kaifu K, Fujita Y, Sofue T, Nakano D, Moriwaki K, et al. Angiotensin II shifts insulin signaling into vascular remodeling from glucose metabolism in vascular smooth muscle cells. Am J Hypertens. (2011) 24:114955. doi: 10.1038/ajh.2011.114

20. Kleinsasser A, Pircher I, Treml B, Schwienbacher M, Schuster M, Janzek E, et al. Recombinant angiotensin-converting enzyme 2 suppresses pulmonary vasoconstriction in acute hypoxia. Wilderness Environ Med. (2012) 23:2430. doi: 10.1016/j.wem.2011.09.002

21. Gaur P, Saini S, Vats P, Kumar B. Regulation, signalling and functions of hormonal peptides in pulmonary vascular remodelling during hypoxia. Endocrine. (2018) 59:466-80. doi: 10.1007/s12020-018-1529-0

22. Makhanova NA, Crowley SD, Griffiths RC, Coffman TM. Gene expression profiles linked to AT1 angiotensin receptors in the kidney. Physiol Genomics. (2010) 42A:211-8. doi: 10.1152/physiolgenomics.00063.2010

23. Bourgonje AR, Abdulle AE, Timens W, Hillebrands JL, Navis GJ, Gordijn $\mathrm{SJ}$, et al. Angiotensin-converting enzyme 2 (ACE2), SARS-CoV-2 and the pathophysiology of coronavirus disease 2019 (COVID-19). J Pathol. (2020) 251:228-48. doi: 10.1002/path.5471

24. Henry BM, Benoit S, Lippi G, Benoit J. Letter to the Editor - Circulating plasma levels of angiotensin II and aldosterone in patients with coronavirus disease 2019 (COVID-19): a preliminary report. Prog Cardiovasc Dis. (2020) 63:702-3. doi: 10.1016/j.pcad.2020.07.006

25. Schneider DS, Ayres JS. Two ways to survive infection: what resistance and tolerance can teach us about treating infectious diseases. Nat Rev Immunol. (2008) 8:889-95. doi: 10.1038/nri2432

26. Wu C, Chen X, Cai Y, Xia J, Zhou X, Xu S, et al. Risk factors associated with acute respiratory distress syndrome and death in patients with coronavirus disease 2019 pneumonia in Wuhan, China. JAMA Intern Med. (2020) 180:934-43. doi: 10.1001/jamainternmed.2020.0994

27. World Health Organization. Clinical Management of COVID-19: Interim Guidance. (2020). Available online at: https://apps.who.int/iris/bitstream/ handle/10665/332196/WHO-2019-nCoV-clinical-2020.5-eng.pdf (accessed December 20, 2021).

28. Baden LR, Rubin EJ. COVID-19 - the search for effective therapy. $N$ Engl $J$ Med. (2020) 382:1851-2. doi: 10.1056/NEJMe2005477

29. Prats-Uribe A, Sena AG, Lai LYH, Ahmed WU, Alghoul H, Alser $\mathrm{O}$, et al. Use of repurposed and adjuvant drugs in hospital patients with Covid-19: multinational network cohort study. BMJ. (2021) 373:n1038. doi: 10.1136/bmj.n1038

30. Williams PB. Renin angiotensin system inhibition as treatment for Covid-19? EClinicalMedicine. (2021) 37:101023. doi: 10.1016/j.eclinm.2021.101023

31. Sharma O, Sultan AA, Ding H, Triggle CR. A review of the progress and challenges of developing a vaccine for COVID-19. Front Immunol. (2020) 11:585354. doi: 10.3389/fimmu.2020.585354

32. Centers for Disease Control and Prevention. Science Brief: COVID-19 Vaccines and Vaccination. (2021). Available online at: https://www.cdc.gov/ coronavirus/2019-ncov/science/science-briefs/fully-vaccinated-people.html (accessed December 20, 2021). 
33. McDonald I, Murray SM, Reynolds CJ, Altmann DM, Boyton RJ. Comparative systematic review and meta-analysis of reactogenicity, immunogenicity and efficacy of vaccines against SARS-CoV-2. NPJ Vaccines. (2021) 6:74. doi: 10.1038/s41541-021-00336-1

34. WHO Solidarity Trial Consortium, Pan H, Peto R, Henao-Restrepo AM, Preziosi MP, Sathiyamoorthy V, et al. Repurposed antiviral drugs for Covid19-interim WHO solidarity trial results. N Engl J Med. (2021) 384:497511. doi: 10.1056/NEJMoa2023184

35. Siemieniuk RA, Bartoszko JJ, Ge L, Zeraatkar D, Izcovich A, Kum E, et al. Drug treatments for Covid-19: living systematic review and network meta-analysis. BMJ. (2020) 370:m2980. doi: 10.1136/bmj.m2980

36. RECOVERY Collaborative Group. Convalescent plasma in patients admitted to hospital with COVID-19 (RECOVERY): a randomised controlled, open-label, platform trial. Lancet. (2021) 397:2049-59. doi: 10.1016/S0140-6736(21)00897-7

37. Baral R, Tsampasian V, Debski M, Moran B, Garg P, Clark A, et al. Association between renin-angiotensin-aldosterone system inhibitors and clinical outcomes in patients with COVID-19: a systematic review and meta-analysis. JAMA Netw Open. (2021) 4:e213594. doi: 10.1001/jamanetworkopen.2021.3594

38. Haroon S, Subramanian A, Cooper J, Anand A, Gokhale K, Byne $\mathrm{N}$, et al. Renin-angiotensin system inhibitors and susceptibility to COVID-19 in patients with hypertension: a propensity scorematched cohort study in primary care. BMC Infect Dis. (2021) 21:262. doi: 10.1186/s12879-021-05951-w

39. Ritchie H, Ortiz-Ospina E, Beltekian D, Macdonald B, Giattino C, OrtizOspina E, et al. Coronavirus Pandemic (COVID-19). (2021). Available online at: https://ourworldindata.org/coronavirus (accessed December 20, 2021).

40. National Institutes of Health. Prevention and Prophylaxis of SARS-CoV-2 Infection. (2020). Available online at: https://www. covid19treatmentguidelines.nih.gov/overview/prevention-of-sars-cov-2 (accessed December 20, 2021).

41. Bartoszko JJ, Siemieniuk RAC, Kum E, Qasim A, Zeraatkar D, Ge L, et al. Prophylaxis against Covid-19: living systematic review and network metaanalysis. BMJ. (2021) 373:n949. doi: 10.1136/bmj.n949

42. Dubina MV, Gomonova VV, Taraskina AE, Vasilyeva NV, Sayganov SA. Pathogenesis-based preexposure prophylaxis associated with a low risk of SARS-CoV-2 infection in healthcare workers at a designated COVID-19 hospital: a pilot study. BMC Infect Dis. (2021) 21:536. doi: 10.1186/s12879-02106241-1
43. Casoni GL, Chitano P, Pinamonti S, Chicca M, Ciaccia A, Fabbri L, et al. Reducing agents inhibit the contractile response of isolated guinea-pig main bronchi. Clin Exp Allergy. (2003) 33:999-1004. doi: 10.1046/j.1365-2222.2003.01710.x

44. Deshpande DA, Wang WC, McIlmoyle EL, Robinett KS, Schillinger RM, An SS, et al. Bitter taste receptors on airway smooth muscle bronchodilate by localized calcium signaling and reverse obstruction. Nat Med. (2010) 16:1299-304. doi: 10.1038/nm.2237

45. Haddy FJ, Vanhoutte PM, Feletou M. Role of potassium in regulating blood flow and blood pressure. Am J Physiol Regul Integr Comp Physiol. (2006) 290:R546-52. doi: 10.1152/ajpregu.00491. 2005

46. Módis K, Gero D, Nagy N, Szoleczky P, Tóth ZD, Szabó C. Cytoprotective effects of adenosine and inosine in an in vitro model of acute tubular necrosis. Br J Pharmacol. (2009) 158:1565-78. doi: 10.1111/j.1476-5381.2009.00 432.x

47. Mann JS, Holgate ST, Renwick AG, Cushley MJ. Airway effects of purine nucleosides and nucleotides and release with bronchial provocation in asthma. J Appl Physiol. (1986) 61:1667-76. doi: 10.1152/jappl.1986.61.5.1667

48. Griese M, Ramakers J, Krasselt A, Starosta V, Van Koningsbruggen S, Fischer $\mathrm{R}$, et al. Improvement of alveolar glutathione and lung function but not oxidative state in cystic fibrosis. Am J Respir Crit Care Med. (2004) 169:8228. doi: 10.1164/rccm.200308-1104OC

Conflict of Interest: The author declares that the research was conducted in the absence of any commercial or financial relationships that could be construed as a potential conflict of interest.

Publisher's Note: All claims expressed in this article are solely those of the authors and do not necessarily represent those of their affiliated organizations, or those of the publisher, the editors and the reviewers. Any product that may be evaluated in this article, or claim that may be made by its manufacturer, is not guaranteed or endorsed by the publisher.

Copyright (C) 2022 Dubina. This is an open-access article distributed under the terms of the Creative Commons Attribution License (CC BY). The use, distribution or reproduction in other forums is permitted, provided the original author(s) and the copyright owner(s) are credited and that the original publication in this journal is cited, in accordance with accepted academic practice. No use, distribution or reproduction is permitted which does not comply with these terms. 